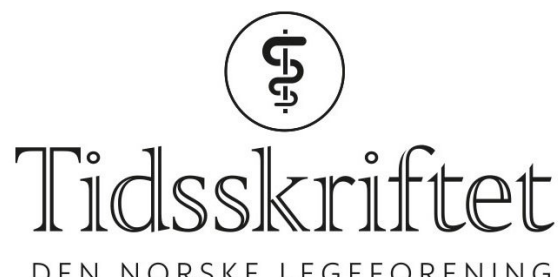

DEN NORSKE LEGEFORENING

\title{
Pakken er åpnet
}

FRA REDAKTØREN

\section{LISE SKOGSTAD LOFTSGAARD}

E-post: lise.skogstad.loftsgaard@tidsskriftet.no

Lise Skogstad Loftsgaard er lege og medisinsk redaktør i Tidsskriftet.

Med pakkeforløpene i psykisk helsevern ønsker man å spare tid og hjelpe flere. Men fører det til bedre hjelp?

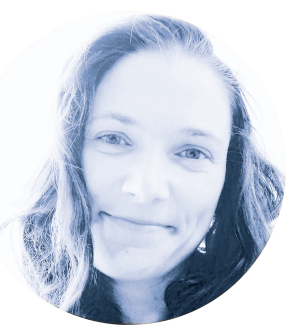

Foto: privat

Forventning, glanset papir og skinnende sløyfebånd. Helsedirektoratets pakke til psykisk helsevern høsten 2018 glitret av viktige mål som $\emptyset$ kt brukermedvirkning, brukertilfredshet og pårørendeinvolvering (1). Pakken ble offisielt åpnet ved nyttår 2019. I slutten av januar 2020 forelå SINTEFs første evalueringsrapport (2).

Pakkeforløpene for psykisk helse og rus skulle imøtekomme behovet for mer sammenhengende og koordinerte tjenester (1, s.1) og er inspirert av pakkeforløp fra kreftomsorgen og tilsvarende danske utredningsmodeller for psykiske lidelser. I Danmark innførte man psykiatriske utrednings- og behandlingspakker allerede i 2013 (3). Definerte timeantall var et sentralt virkemiddel. For eksempel ga basis utredningspakke i barne- og ungdomspsykiatri mulighet for inntil 6,5 timers utredning fordelt på 3-6 ytelser (4). Der symptombildet var sammensatt og diagnostikken utfordrende, hadde man mulighet til å utvide utredningstiden noe.

I 2015 frarådet danske leger norske helsemyndigheter å benytte presise tidsangivelser når de psykiatriske pakkeforløpene skulle etableres (5). Deres erfaringer var at det ikke fungerte. Blant annet viste behandlingsressursene seg å være så små at det ikke var mulig å innfri timetallene i de enkelte pakkene. Disse erfaringene forelå før den norske implementeringen. Likevel sitter klinikere nå og jobber mot klokka i nye pakkeforløp for psykisk helsevern.

Erfaringer fra Danmark viser at de mest hjelpetrengende psykiatriske pasientene har størst sannsynlighet for å ikke få plass i pakken som er ment å hjelpe dem (6). Det kan også være utfordrende å få benyttet spesialistkompetansen optimalt innenfor pakkenes rammer (7). Da danske behandlere ble intervjuet om sine erfaringer med innføringen av de nasjonale 
psykiatripakkene, var en gjentakende utfordring at tiden ikke strakk til for de gode kliniske vurderingene og at det kunne resultere i behandling som ikke svarte til det egentlige behovet (8).

SINTEFs pågående evaluering av det norske pakkeforløpet for psykisk helse og rus skal gi kunnskap om pasienters og tjenesteyteres erfaringer og om pakkeforløpene innfrir intensjonene (9). En ettårsrapport over tjenesteyteres erfaringer forelå i slutten av januar 2020 (2). Den kan - ikke helt uventet - sies å være noe nedslående. Rapporten dekker alle pakkeforløpene for psykisk helsevern, både for barn og for voksne. SINTEF konkluderer blant annet med at dersom pakkeforløp blir et for rigid system, er det en fare for at man overser spesielle behov hos brukerne.

I rapporten framkommer det at rundt 6o \% av behandlere i psykisk helsevern for barn og unge opplever at pakkeforløp i liten grad eller ikke i det hele tatt bidrar til mer sammenhengende eller mer koordinerte pasientforløp (2). Knappe $5 \%$ mener at pakkeforløpene i stor grad innfrir intensjonene. Helsemyndighetene mener at dette fordrer ytterligere krav og forpliktelser for helseforetakene (9). Men er det egentlig det som er den beste løsningen? De røde tallene sier ikke noe om grunnen til at tiden bokstavelig talt forløp fra oss.

Pakkeforløpene benytter forløpskoder for å følge med på om målsetningene nås. En sentral indikator som skal kodes er forløpstiden, som ikke skal overskride en gitt grense. For eksempel er maksimal forløpstid til basisutredning av psykiske lidelser hos barn og unge 42 kalenderdager. Første møte med pasienten, tilbakemelding til fastlegen, klinisk beslutning om diagnose og evaluering av behandlingseffekt er andre elementer som skal kodes. Det synes derimot ikke relevant om den fastsatte diagnosen er riktig eller om behandlingen virker.

Siden pakkeforløpet bare etterspør om effektevalueringen er gjennomført, kan effekten av behandlingen utebli uten at tallene blir røde

I teorien kan altså tallene lyse grønne, mens en ukonsentrert ungdom begynner å ta metylfenidat for en hyperkinetisk forstyrrelse som vedkommende ikke har. Og siden pakkeforløpet bare etterspør om effektevalueringen er gjennomført, kan effekten av behandlingen utebli uten at tallene blir røde. Det er prisverdig å ville sikre brukermedvirkning og forutsigbarhet og å øke kvaliteten på tjenesten, men da er systemet man innfører også nødt til å måle kvalitet.

Når man jobber mot ukontrollert celledeling ved kreftlidelser, er det kvalitet å måle forløpstiden med en intensjon om å forkorte den. I møte med et menneske med en psykisk lidelse vil det derimot være en kunstfeil å se på klokka istedenfor pasienten. Pakken er åpnet, men vi fikk ikke det vi ønsket oss.

LITTERATUR:

1. Helsedirektoratet. Nasjonal plan for implementering av pakkeforløp for psykisk helse og rus 2018-2020.

https://www.helsedirektoratet.no/pakkeforlop/dokumenter-pakkeforlop\%2opsykisk\%2ohelse\%2oog\%2 orus/Pakkeforl\%C3\%B8p\%2ofor\%2opsykisk\%2ohelse\%2oog\%2orus\%2O-

\%2onasjonal\%2oplan\%2ofor\%2oimplementering\%202018-2020.pdf/_/attachment/inline/8b6fb586-8e1c$423 \mathrm{a}-$

ao54-376abee6827e:cd98f32681d7C5C52fad3a578d7ogffcdbe744a2/Pakkeforl\%C3\%B8p\%2ofor\%2opsykisk\% 2ohelse\%20og\%2orus\%20-\%2onasjonal\%2oplan\%2ofor\%2oimplementering\%202018-2020.pdf Lest 6.5.2020.

2. Ådnanes M, Kaspersen SL, Melby L et al. Pakkeforløp for psykisk helse og rus - fagfolks erfaringer første året. SINTEF-rapport 2020:00o64.

https://www.helsedirektoratet.no/nyheter/evaluering-av-pakkeforlop-for-psykisk-helse-og-rus/Evaluer ing\%20av\%2opakkeforl\%C3\%B8p\%2opsykisk\%2ohelse\%2oog\%2orus.pdf/_/attachment/inline/b8oaodo3- 
4ea5-4577-8737-1afgcoacca54:13edcea72885cf788b2ofa1e7oagb9c94054d53f/Evaluering\%2oav\%2opakkefor 1\%C3\%B8p\%2opsykisk\%2ohelse\%20og\%2orus.pdf Lest 6.5.2020.

3. Region Syddanmark. Psykiatripakker.

https://www.sundhed.dk/sundhedsfaglig/information-til-praksis/syddanmark/almen-praksis/patientf orloeb/psykiatri/ Lest 6.5.2020.

4. Danske Regioner. Børne- og ungdomspsykiatri. Udredningspakkeforløb.

https://www.sundhed.dk/content/cms/91/43091_pakkeforl\%C3\%B8b-b\%C3\%B8rn-og-unge-feb13-2-(2).pdf Lest 6.5.2020.

5. Heinskou T, Alberdi F, Jordet H. Psykiatriske behandlingspakker: Erfaringer fra Danmark.

Morgenbladet 21.9.2015.

https://morgenbladet.no/ideer/2015/o9/psykiatriske-behandlingspakker-erfaringer-fra-den-danske-kli niske-dagligdag Lest 6.5.2020.

6. Rossen CB, Buus N, Stenager E et al. The role of assessment packages for diagnostic consultations: A conversation analytic perspective. Health (London) 2015; 19: 294-317. [PubMed][CrossRef]

7. Rossen CB, Buus N, Stenager E et al. Patient assessment within the context of healthcare delivery packages: A comparative analysis. Int J Nurs Stud 2016; 53: 248-59. [PubMed][CrossRef]

8. Trojaborg RS. Enhanced quality or assembly lines? Psychiatric treatment packages in Denmark: knowledge definitions and governing tools. Soc Theory Health 2018; 16:342-6o. [CrossRef]

9. Storvik AG. Psykisk helse: Høie med krav til sykehusene etter nedslående rapport. Dagens Medisin 28.2.2020.

https://www.dagensmedisin.no/artikler/2020/02/28/psykisk-helse-hoie-med-krav-til-sykehusene-etternedslaende-rapport/ Lest 6.5.2020.

Publisert: 19. mai 2020. Tidsskr Nor Legeforen. DOI: 10.4045/tidsskr.20.0427

(C) Tidsskrift for Den norske legeforening 2020. Lastet ned fra tidsskriftet.no 